\title{
Sinergi Dosen dan Mahasiswa dalam Pemberdayaan Wanita di Desa Koripan, Kecamatan Matesih, Kabupaten Karanganyar
}

\author{
Dimas Rahadian Aji Muhammad ${ }^{1 *}$, Fanny Widadie² dan Bambang Sigit Amanto \\ ${ }^{1}$ Program Studi Ilmu Teknologi Pangan, Fakultas Pertanian, Universitas Sebelas Maret, Surakarta, Indonesia; \\ ${ }^{2}$ Program Studi Agribisnis, Fakultas Pertanian, Universitas Sebelas Maret, Surakarta, Indonesia
}

Diterima: 19 April 2020; Disetujui: 13 Agustus 2020

\begin{abstract}
Abstrak
Mahasiswa dikenal sebagai agen perubahan yang dapat berperan besar dalam perubahan kehidupan sosial suatu kelompok masyarakat. Namun, seringkali idealisme para mahasiswa sering terhambat oleh ketersediaan dana. Di lain pihak, seseorang yang berprofesi sebagai seorang dosen di sebuah perguruan tinggi mempunyai kewajiban untuk melaksanakan Tri Dharma Perguruan Tinggi, yang salah satunya adalah melakukan kegiatan pengabdian masyarakat. Dalam pelaksanaannya, seorang dosen mempunyai berbagai kesempatan untuk meraih dana dari beragam lembaga penyandang dana. Artikel ini membahas pelaksanaan kegiatan pengabdian masyarakat yang dilakukan secara sinergi oleh kelompok dosen dengan para mahasiswa yang tergabung dalam Himpunan Mahasiswa Ilmu Teknologi Pangan (HIMAGHITA) Universitas Sebelas Maret di Desa Koripan, Kecamatan Matesih, Kabupaten Karanganyar. Tujuan dari kegiatan pengabdian masyarakat ini adalah menerapkan teknologi pengolahan ubi jalar ungu dan jagung serta peningkatan pengetahuan manajemen industri pangan pada kelompok wanita tani di wilayah tersebut. Kegiatan yang dilakukan meliputi introduksi teknologi pembuatan tepung, pengolahan cookies ubi jalar ungu dan brownies jagung. Berdasarkan hasil monitoring dan evaluasi, dapat disimpulkan sinergi dosen dan mahasiswa dapat secara efektif mendukung program pengabdian masyarakat, serta introduksi teknologi pengolahan ubi jalar ungu dan jagung dapat diimplementasikan dengan baik. Selain itu, pengetahuan kelompok wanita tani mengenai manajemen industri pangan skala rumah tangga meningkat setelah kegiatan ini dilakukan.
\end{abstract}

Kata kunci: dosen; Karanganyar; mahasiswa; pemberdayaan masyarakat

\section{Synergy between Lecturer and Student in the Woman Community Empowerment in the Village of Koripan, Matesih Sub-district, Karanganyar Regency}

\section{Abstract}

Higher education student is known as agent of change that can play a significant role on the transformation of the social life of a society. However, the idealism of students is often hampered by the availability of funds. On the other hand, someone who works as a lecturer at a higher education has a responsibility to do the three pillars of higher education (Tri Dharma Perguruan Tinggi), one of which is to carry out community service activities. To carry out the community service, a lecturer has many opportunities to obtain funds from various funding bodies. This article discusses the community service activity that was done by implementing a synergy between a group of lecturers

\footnotetext{
*Corresponding author: dimasrahadian@staff.uns.ac.id

Cite this as: Muhammad, D. R. A., Widadie, F., \& Amanto, B. A. (2020). Sinergi Dosen dan Mahasiswa dalam Pemberdayaan Wanita di Desa Koripan, Kecamatan Matesih, Kabupaten Karanganyar. AgriHealth: Journal of Agri-food, Nutrition and Public Health, 1(2), 47-54. doi: http://dx.doi.org/10.20961/agrihealth.v1i2.41226
} 
and students who are the members of the Food Science Technology Student Association (HIMAGHITA) Universitas Sebelas Maret in the Village of Koripan, Matesih Sub-district, Karanganyar Regency. The purpose of the community service activity is to introduce the processing technology of purple sweet potato and corn and to increase the knowledge of food industry management in the group of women farmers in the region. The community service activity included the introduction of flour-making technology, processing technology of purple sweet potato cookies and corn brownies. Based on the results of monitoring and evaluation, it can be concluded that the synergy of lecturers and students can effectively support the community service activity and the introduction of purple sweet potato and corn processing technology can be well-carried out. In addition, the knowledge of farmer women's groups on the management of home-scale food industry increased after this activity was carried out.

Keywords: community empowerment; Karanganyar; lecturer; student

\section{PENDAHULUAN}

Desa Koripan merupakan suatu desa yang berlokasi di Kecamatan Matesih, Kabupaten Karanganyar. Survei pendahuluan yang dilakukan pada awal Tahun 2013 oleh Tim Pengabdian Universitas Sebelas Maret menunjukkan bahwa secara demografi, Desa Koripan berpenduduk sekitar 4.826 orang dengan jenis kelamin lakilaki 2.301 orang dan perempuan 2.525 orang. Penduduk dengan kategori umur kelompok pra sekolah (0-6 tahun) sebanyak 425 orang, kelompok usia (7-19 tahun ke atas) sebanyak 1.773 orang dan kelompok usia kerja (19-57 tahun) sebanyak 2.628 orang. Penduduk dengan kategori pekerjaan terbanyak karyawan negeri dan swasta 286, wiraswasta/pedagang 786, petani 762 , buruh tani 382 orang, serta sisanya adalah bekerja serabutan dan pengangguran. Penduduk yang tidak/belum pernah SD sebanyak 1.232 orang, lulusan pendidikan umum (SD sampai Pasca Sarjana) sebanyak 1.184 orang dan lulusan pendidikan khusus (Pondok Pesantren, Pendidikan Keagamaan dan lain-lain) sebanyak 260 orang. Data Desa Koripan menunjukkan bahwa penduduk miskin pada Tahun 2012 sekitar 262 Kepala Keluarga (KK), yaitu dengan indikator penerima beras miskin (Raskin).

Secara monografi Desa Koripan, luas wilayah desa sekitar 248,035 ha dengan ketinggian tanah $500 \mathrm{~m}$ di atas permukaan air laut dan dengan suhu udara rata-rata $23^{\circ} \mathrm{C}$, sehingga sangat cocok untuk menanam padi, palawija dan sayur-sayuran seperti padi, jagung, ketela pohon, ketela rambat, kubis, sawi dan lain-lain. Desa Koripan terletak di lereng Gunung Lawu, sehingga potensi sumber daya pertanian tersedia secara melimpah. Berbagai hasil pertanian di Desa Koripan masih jarang untuk diolah menjadi produk yang bernilai jual. Kebanyakan masyarakat memanfaatkan bahan lokal yang di daerahnya hanya untuk konsumsi rumah tangga atau dijual dalam bentuk segar. Hariyanto et al. (2017) menyatakan bahwa hasil pertanian yang belum diolah mempunyai nilai jual yang rendah, serta proses pengolahan dapat meningkatkan nilai tambah hasil pertanian tersebut secara signifikan. Berdasarkan hal tersebut, peningkatan kreativitas masyarakat Desa Koripan untuk mengolah hasil pertanian menjadi suatu produk pangan bernilai jual perlu dilakukan. Rendahnya tingkat pengetahuan dari masyarakat biasanya menjadi faktor utama yang menyebabkan kurangnya daya cipta produk baru di masyarakat. Salah satu contoh produk di Desa Koripan yang masih mempunyai nilai jual rendah adalah ubi jalar ungu dan jagung.

Melihat situasi tersebut, mahasiswa Program Studi Ilmu Teknologi Pangan, Universitas Sebelas Maret (UNS) yang tergabung dalam Himpunan Mahasiswa Ilmu Teknologi Pangan (HIMAGHITA) menjadikan Desa Koripan sebagai desa binaan sejak tahun 2010. Hal ini sesuai dengan visi organisasi tersebut yaitu "Menjadikan HIMAGHITA sebagai wadah terciptanya insan akademis yang profesional, edukatif dan berjiwa sosial" (HIMAGHITA, 2019). Dalam hal ini, HIMAGHITA sedang menjalankan perannya sebagai agen perubahan. Menurut Sari et al. (2018), mahasiswa menyandang tiga fungsi strategis sekaligus, yaitu sebagai agen kontrol sosial (agent of social control), sebagai agen perubahan (agent of change) dan sebagai generasi penerus masa depan (iron stock). Program kerja yang dilakukan HIMAGHITA di Desa Koripan pada dasarnya merupakan kegiatan pemberdayaan, yaitu suatu proses pembangunan dimana masyarakat berinisiatif untuk memulai proses kegiatan sosial 
untuk memperbaiki situasi dan kondisi mereka. Menurut Mufidah dan Adi (2018), pemberdayaan merupakan konsep yang setara dengan konsep Pengembangan Masyarakat (Community Development) dan sering digunakan untuk mengatasi permasalahan terkait kemiskinan dan kesejahteraan di era saat ini. Melalui programprogramnya, HIMAGHITA telah berusaha untuk turut membantu pengembangan hasil pertanian di Desa Koripan, sehingga saat ini sudah terbentuk sebuah industri kecil skala rumah tangga dengan nama "Ganoman". Namun, karena terbatasnya sumberdaya dan dana pada HIMAGHITA, program tersebut belum dapat berlanjut dengan optimal.

Dosen merupakan profesi yang mempunyai posisi strategis untuk melakukan kegiatan pemberdayaan masyarakat. Definisi dari profesi dosen telah ditegaskan dalam Peraturan Pemerintah Republik Indonesia Nomor 37 Tahun 2009 pada Pasal 1 Ayat 1, yaitu yang berbunyi "Dosen adalah pendidik profesional dan ilmuwan dengan tugas utama mentransformasikan, mengembangkan dan menyebarluaskan ilmu pengetahuan, teknologi dan seni melalui pendidikan, penelitian dan pengabdian kepada masyarakat". Kewajiban melaksanakan Pendidikan (pengajaran), penelitian dan pengabdian masyarakat dikenal secara populer dengan nama Tri Dharma Perguruan Tinggi. Dalam melaksanakan tugas Tri Dharma Perguruan Tinggi, termasuk kegiatan pengabdian masyarakat, seorang dosen berkesempatan untuk mendapatkan dana dari beragam sumber, termasuk dari pemerintah pusat, pemerintah daerah serta institusi dimana dosen tersebut bernaung. Namun, seringkali karena keterbatasan waktu dan tenaga, seorang dosen tidak dapat melakukan kegiatan pengabdian masyarakat secara berkelanjutan. Oleh karena itu, bantuan tenaga dari mahasiswa sangat diperlukan.

Menimbang situasi yang dihadapi oleh pihak dosen dan pihak mahasiswa, maka sinergi antara dosen dengan mahasiswa, dalam hal ini HIMAGHITA, sangat diperlukan. Sinergi tersebut diharapkan dapat mengoptimalkan program pengabdian masyarakat di Desa Koripan, sehingga cita-cita untuk mengangkat hasil pertanian lokal, khususnya ubi jalar ungu dan jagung, agar mempunyai nilai ekonomi yang tinggi dapat tercapai. Berdasarkan seluruh permasalahan yang teridentifikasi, telah disepakati bersama antara tim pengabdian masyarakat UNS dan masyarakat Desa Koripan bahwa beberapa permasalahan yang diprioritaskan untuk diselesaikan adalah (1) melimpahnya produksi ubi jalar ungu dan jagung yang belum mampu mensejahterakan masyarakat akibat harga jual yang relatif rendah; (2) jumlah masyarakat miskin yang masih banyak; serta (3) kurang sosialisasi, minat, pengetahuan dan wawasan masyarakat tentang ilmu dan teknologi pengolahan hasil pertanian. Tujuan dari kegiatan ini adalah memperkenalkan teknologi pengolahan ubi jalar ungu dan jagung menjadi tepung, cookies dan brownies kepada kelompok wanita tani di Desa Koripan. Cookies dan brownies dipilih sebagai produk yang dikembangkan pada kegiatan ini karena kedua produk tersebut telah dikenal secara luas produknya di masyarakat umum, sehingga mempunyai peluang pasar yang baik apabila telah diproduksi secara kontinyu. Pada akhir kegiatan, evaluasi efektivitas sinergi antara dosen dan mahasiswa dalam melaksanakan kegiatan pengabdian masyarakat juga dilakukan.

\section{BAHAN DAN METODE}

\section{Tempat dan waktu pelaksanaan}

Kegiatan pengabdian masyarakat ini dilaksanakan di Dusun Gugur, Desa Koripan, Kecamatan Matesih, Kabupaten Karanganyar pada bulan Maret 2013 hingga September 2014.

\section{Bahan yang digunakan}

Bahan utama yang digunakan dalam kegiatan pengabdian masyarakat ini adalah ubi jalar ungu dan jagung yang diproduksi di Desa Koripan.

\section{Metode serta langkah-langkah pelaksanaan \\ Introduksi teknologi pengolahan tepung ubi jalar ungu dan tepung jagung}

Tahapan proses pembuatan tepung ubi jalar ungu dan tepung jagung dapat dilihat pada Gambar 1 dan Gambar 2. Pengupasan dilakukan secara manual dengan pisau dan tangan. Sebelum dilakukan pengeringan, jagung dipipil terlebih dahulu, sedangkan ubi jalar dipotong-potong untuk mengecilkan ukuran dan memudahkan proses pengeringan. Pengeringan dilakukan dengan metode sun-drying hingga kadar air mencapai sekitar $10 \%$. Penggilingan dilakukan dengan mesin penggiling untuk membentuk tepung dan selanjutnya dilanjutkan dengan pengayakan 60 mesh untuk mendapatkan ukuran tepung ubi jalar ungu dan tepung jagung yang seragam. 


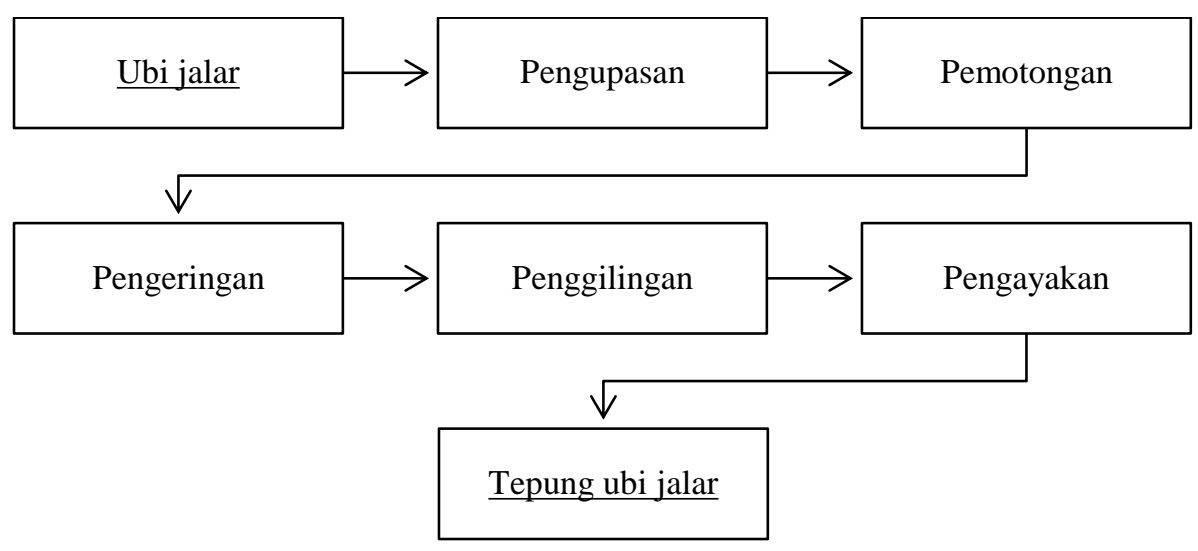

Gambar 1. Cara pembuatan tepung ubi jalar ungu

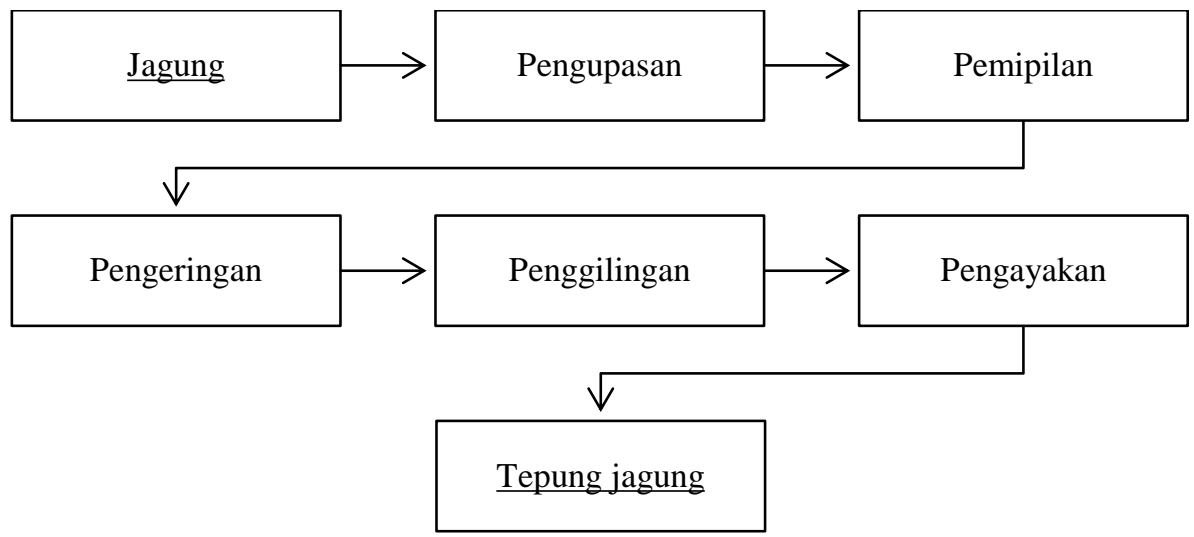

Gambar 2. Cara pembuatan tepung jagung

Introduksi teknologi pengolahan cookies ubi jalar ungu

Bahan yang digunakan untuk membuat cookies ubi jalar ungu adalah tepung ubi jalar $60 \mathrm{~g}$, tepung terigu $140 \mathrm{~g}$, kuning telur 2 butir, susu skim $15 \mathrm{~g}$, gula halus $70 \mathrm{~g}$, soda kue $0,4 \mathrm{~g}$ dan margarin $110 \mathrm{~g}$. Proses pembuatan cookies dilakukan dengan proses pencampuran pertama, yaitu mencampurkan margarin, gula halus dan susu skim dengan mixer kecepatan putaran tinggi selama 3-7 menit hingga campuran menjadi homogen. Pencampuran kedua dengan tepung dilakukan dengan kecepatan putaran sedang selama 1-3 menit. Setelah itu, adonan dicetak dan dioven dengan suhu $130^{\circ} \mathrm{C}$ selama 20 menit.

\section{Introduksi teknologi produksi brownies jagung}

Bahan yang digunakan untuk membuat brownies, yaitu tepung jagung, bahan margarin, telur, gula pasir, tepung terigu, susu bubuk dan cokelat. Brownies jagung dibuat dengan mencampurkan $250 \mathrm{~g}$ margarin dan $200 \mathrm{~g}$ cokelat dan dilanjutkan proses tim hingga meleleh. Secara terpisah, 5 butir telur dikocok bersama $200 \mathrm{~g}$ gula pasir hingga mengembang. Selanjutnya, campuran margarin dan cokelat yang sudah meleleh, $250 \mathrm{~g}$ tepung terigu, $150 \mathrm{~g}$ tepung jagung dan $75 \mathrm{~g}$ susu bubuk diaduk hingga merata bersama campuran telur dan gula pasir tersebut. Adonan selanjutnya dituang ke dalam loyang bulat berdiameter $18 \mathrm{~cm}$ yang telah dialasi kertas roti dan diolesi margarin. Adonan dipanggang dalam oven bersuhu $180^{\circ} \mathrm{C}$ selama 30 menit atau hingga matang.

\section{Evaluasi serta monitoring pelaksanaan pengabdian masyarakat}

Evaluasi dan monitoring dilakukan secara periodik melalui observasi lapangan untuk mengetahui tingkat pencapaian transfer ilmu pengetahuan pengolahan ubi jalar ungu dan jagung kepada masyarakat sasaran. Wawancara dengan pejabat Desa Koripan dan pengurus HIMAGHITA yang dipilih melalui purposive sampling dilakukan untuk mengetahui tingkat efektivitas sinergi antara dosen dan mahasiswa 
dalam kegiatan pengabdian masyarakat ini. Hasil dari evaluasi dan monitoring disajikan secara kualitatif deskriptif yang dimaksudkan untuk mendeskripsikan suatu variabel secara ringkas dan jelas. Data yang diperoleh melalui riset deskriptif dapat digunakan untuk analisis lebih lanjut untuk menarik kesimpulan (Riptanti et al., 2018).

\section{HASIL DAN PEMBAHASAN}

\section{Introduksi teknologi pengolahan ubi jalar ungu dan jagung}

Tim pengabdian masyarakat UNS bersama dengan HIMAGHITA telah melakukan introduksi teknologi pengolahan hasil pertanian sebagai bentuk pemberdayaan masyarakat Desa Koripan yang meliputi pembuatan tepung, cookies ubi jalar ungu dan brownies jagung (Gambar 3). Dalam bentuk tepungnya, ubi jalar ungu maupun jagung mempunyai umur simpan yang lebih lama serta lebih mudah didistribusikan dan digunakan untuk berbagai keperluan (Aini et al., 2016; Firgianti and Sunyoto, 2018). Selanjutnya, tepung ubi jalar ungu diolah menjadi cookies, sedangkan tepung jagung diolah menjadi brownies. Pemilihan cookies dan brownies sebagai bentuk olahan dari tepung ubi jalar ungu dan jagung didasarkan pada pertimbangan bahwa kedua produk tersebut merupakan produk makanan yang populer di masyarakat.

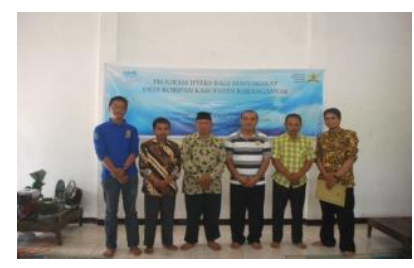

Penyerahan alat

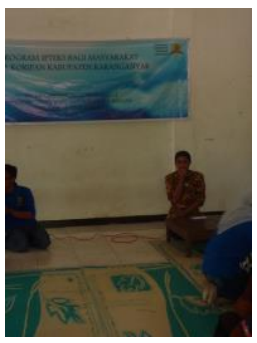

Penyampaian materi oleh tim pengabdian UNS

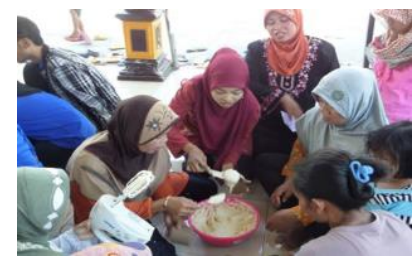

Praktek langsung pengolahan ubi jalar ungu dan jagung

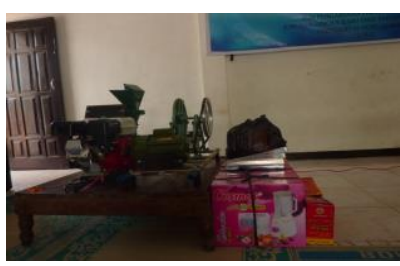

Sebagian peralatan yang diperbantukan

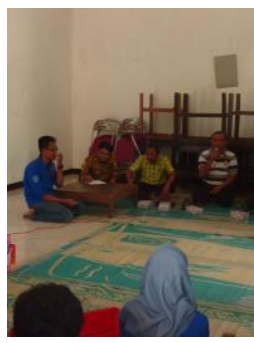

Penyampaian materi oleh tim pengabdian UNS

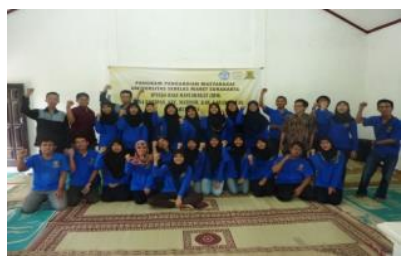

Keterlibatan mahasiswa HIMAGHITA

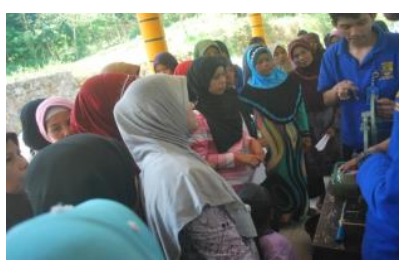

Introduksi peralatan pengolahan oleh mahasiswa

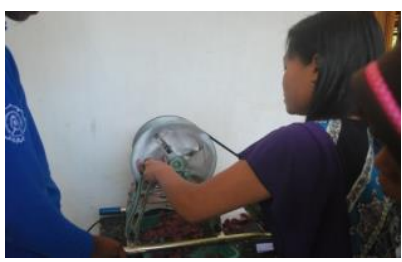

Praktek langsung pengolahan ubi jalar ungu dan jagung

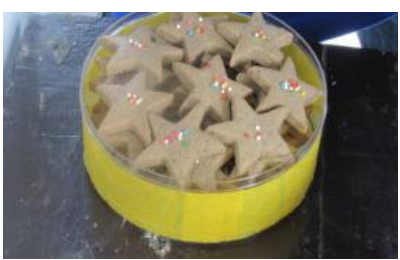

Contoh produk yang dihasilkan

Gambar 3. Dokumentasi kegiatan pengabdian masyarakat di Desa Koripan, Kecamatan Matesih, Kabupaten Karanganyar

Pelatihan teknologi pengolahan cookies dan brownies dilakukan menjelang Bulan Ramadhan dan Hari Raya Idul Fitri. Hal ini dimaksudkan agar momentum tersebut dapat dimanfaatkan semaksimal mungkin oleh masyarakat untuk memproduksi, memasarkan dan mendapatkan keuntungan dari kue kering jagung. Namun dari hasil pemantauan, pada momentum tersebut belum dimanfaatkan secara optimal oleh masyarakat sasaran. Hal ini terjadi karena diperkirakan para peserta pelatihan belum siap menerima perubahan sosial yang diperkenalkan oleh tim pengabdian UNS. Kondisi sosial budaya yang berkembang di masyarakat sangat 
mempengaruhi kecepatan adopsi suatu sistem baru yang sedang dikenalkan kepada masyarakat, termasuk sistem-sistem baru pada bidang pertanian. Hal ini mengindikasikan bahwa pendampingan terhadap kelompok masyarakat sasaran harus dilakukan secara berkelanjutan.

Selain melakukan kegiatan introduksi teknologi pengolahan ubi jalar ungu dan jagung, tim pengabdian masyarakat UNS juga menyerahkan satu set perlengkapan alat pembuatan tepung, cookies dan brownies yang sudah diintroduksikan kepada kelompok wanita tani di Desa Koripan. Dalam kegiatan tersebut juga disepakati bahwa peralatan yang diperbantukan akan diletakkan di Balai Rukun Warga dengan pertimbangan akses lokasi penyimpanan yang relatif mudah, peralatan dapat dimanfaatkan seluruh warga yang membutuhkan serta menghindari klaim sebagai peralatan milik pribadi. Penyerahan alat dimulai dengan penyerahan secara simbolis, kemudian dilanjutkan dengan penandatanganan berita acara penyerahan alat. Penyerahan bantuan peralatan ini diharapkan dapat membantu rintisan usaha atau industri kecil olahan ubi jalar ungu dan jagung yang dikelola oleh kelompok wanita tani Desa Koripan, sehingga hasil dari kegiatan pengabdian masyarakat ini berdampak jangka panjang.

Berdirinya industri pangan berbasis ubi jalar ungu dan jagung di Desa Koripan ini merupakan wujud dari keberlanjutan program pengabdian pada masyarakat yang dilakukan oleh tim pengabdian UNS. Adanya industri pangan ini ditujukan untuk meningkatkan kemandirian masyarakat desa dalam mengembangkan dan meningkatkan ekonomi. Pelatihan kewirausahaan secara kompleks diperlukan dalam memulai sebuah usaha baru, baik internal berupa penumbuhan semangat dan motivasi untuk berwirausaha maupun secara eksternal yang berfokus pada pelatihan manajemen operasional. Dengan demikian, untuk melengkapi kegiatan introduksi teknologi pengolahan ubi jalar ungu dan jagung, tim pengabdian masyarakat UNS juga melakukan kegiatan pelatihan yang meliputi motivasi dan semangat kewirausahaan serta kegiatan pembukuan keuangan sederhana dan analisis ekonomi industri pangan.

Tujuan dari kegiatan pemberian motivasi dan semangat kewirausahaan ini adalah menanamkan jiwa semangat kewirausahaan kepada masyarakat Desa Koripan untuk mau menjalankan usaha industri pangan berbasis ubi jalar ungu dan jagung dalam meningkatkan pendapatan masyarakat. Motivasi kewirausahaan ini dilakukan dengan ceramah, diskusi, permainan kerjasama dan memberikan contoh para pelaku UKM yang telah sukses menjalankan usaha. Dari hasil evaluasi kegiatan yang dilakukan, membangun semangat dan jiwa wirausaha kepada penduduk desa adalah sesuatu hal yang tidak mudah untuk dilakukan. Pada umumnya penduduk Desa Koripan memang sudah merasa nyaman dengan kehidupan yang sudah dijalani sehingga semangat untuk melakukan perubahan masih rendah. Sehingga upaya stimulus kemudian diarahkan kepada pemberian pengarahan teknologi praktis penerapan usaha sederhana yang menjanjikan untuk menambah pendapatan masyarakat desa. Pemberian bantuan peralatan merupakan salah satu bentuk stimulus yang diberikan oleh tim pengabdian masyarakat UNS kepada masyarakat Desa Koripan.

Kegiatan pelatihan pembukuan sederhana untuk usaha kecil diperlukan untuk mengatur arus kas masuk dan keluar selama proses usaha. Pelatihan pencatatan pembukuan dilakukan dengan menerapkan pembukuan-akuntansi secara sederhana dengan mencatat segala macam pengeluaran dan pemasukan ke dalam buku jurnal dan laporan laba/rugi. Berdasarkan hasil diskusi memang yang menjadi kendala dalam usaha pangan berbahan jagung adalah modal. Pemberian modal usaha berupa peralatan proses produksi memang sangat membantu akan tetapi kebutuhan kontinuitas bahan proses produksi masih menjadi kendala. Oleh karena itu, melalui pemberian strategi modal diberikan dalam upaya mengatasi permasalahan modal awal.

Hasil evaluasi kegiatan yang dilakukan dengan metode wawancara mendalam yang dipilih melalui purposive sampling menunjukkan bahwa kegiatan pengabdian mayarakat ini telah berhasil mentransfer sebuah teknologi tepat guna berupa pengolahan pangan berbasis ubi jalar ungu dan jagung. Peserta pengabdian telah secara langsung praktek membuat tepung, cookies ubi jalar ungu dan brownies jagung sehingga dapat disimpulkan bahwa para peserta telah mengenal cara membuat produk-produk tersebut secara baik. Berdasarkan hasil pendampingan oleh HIMAGHITA, tepung ubi jalar ungu dan cookies ubi jalar ungu merupakan produk yang telah mampu diproduksi secara mandiri oleh peserta pengabdian masyarakat di Desa Koripan dan telah layak untuk dijual 
kepada masyarakat umum. Namun, kendala utama masih terletak pada semangat jiwa kewirausahaan pada masyarakat desa untuk dapat mengembangkan menjadi usaha profesional masih kecil. Program pelatihan kewirausahaan yang dilakukan secara terpadu dan berkelanjutan sudah sedikit membantu menumbuhkan pengetahuan dan mengasah kewirausahaan manajemen usaha kecil yang sedang dirintis. Berdasarkan hasil pantauan dan evaluasi saat ini sudah mulai terbuka pasar dengan dibantu mahasiswa dalam kegiatan pemasarannya.

\section{Efektivitas sinergi dosen dan mahasiswa}

Hasil dari evaluasi efektivitas sinergi antara dosen yang direpresentasikan oleh tim pengabdian masyarakat UNS dan mahasiswa yang direpresentasikan oleh HIMAGHITA dapat dilihat pada Tabel 1. Melalui observasi dan evaluasi, terdapat perbedaaan yang signifikan antara sebelum dan sesudah sinergi antara dosen dan mahasiswa dilakukan. Sebelum sinergi dilakukan, kegiatan pengabdian masyarakat yang dilakukan para mahasiswa tidak dapat memberikan bantuan peralatan pengolahan pangan kepada masyarakat sasaran pengabdian.
Hal ini dapat dipahami, sebab para mahasiswa mempunyai keterbatasan dalam pendanaan kegiatan, sedangkan setelah terdapat sinergi, bantuan peralatan yang dibutuhkan masyarakat dapat diberikan. Hal ini memungkinkan dilakukan karena dosen yang tergabung di dalam tim pengabdian masyarakat mendapatkan dana hibah dari Kementerian Pendidikan dan Kebudayaan Republik Indonesia melalui Hibah Kegiatan Pengabdian Pada Masyarakat Mono Tahun dalam skema IbM Tahun 2013 (untuk kegiatan yang dilaksanakan pada tahun 2013) serta dari Universitas Sebelas Maret melalui Hibah Kegiatan Pengabdian Pada Masyarakat Mono Tahun, dalam skema IbM Tahun 2014 (untuk kegiatan yang dilaksanakan pada Tahun 2014). Sinergi dosen dan mahasiswa juga dapat bersifat saling menguntungkan pada aspek ketersediaan tenaga. Tanpa adanya sinergi, dosen akan mempunyai keterbatasan dalam mengerjakan halhal teknis serta melakukan pendampingan di lokasi kegiatan pengabdian masyarakat. Dengan adanya sinergi, hal-hal teknis dan pendampingan kepada para peserta pengabdian masyarakat di Desa Koripan dapat dibantu oleh mahasiswa.

Tabel 1. Perbandingan kondisi kegiatan pengabdian masyarakat antara sebelum dan sesudah adanya sinergi antara dosen dan mahasiswa

\begin{tabular}{|c|c|c|c|}
\hline No. & Variabel pengamatan & Sebelum terdapat sinergi & Setelah terdapat sinergi \\
\hline 1. & $\begin{array}{l}\text { Bantuan peralatan kepada masyarakat } \\
\text { sasaran }\end{array}$ & Tidak dapat dilakukan & Dapat dilakukan \\
\hline 2. & $\begin{array}{l}\text { Ketersediaan dana untuk operasional } \\
\text { kegiatan pengabdian masyarakat }\end{array}$ & $\begin{array}{l}\text { Hanya dari anggaran } \\
\text { kegiatan HIMAGHITA }\end{array}$ & $\begin{array}{l}\text { Didukung oleh dana } \\
\text { pengabdian masyarakat } \\
\text { yang diperoleh dosen }\end{array}$ \\
\hline 3. & $\begin{array}{l}\text { Ketersediaan tenaga yang mengerjakan } \\
\text { hal-hal teknis dalam kegiatan } \\
\text { pengabdian masyarakat }\end{array}$ & $\begin{array}{l}\text { Hanya dilakukan oleh } \\
\text { dosen atau mahasiswa } \\
\text { secara terpisah }\end{array}$ & $\begin{array}{l}\text { Dilakukan oleh dosen } \\
\text { dan mahasiswa secara } \\
\text { terkoordinasi }\end{array}$ \\
\hline 4. & $\begin{array}{l}\text { Frekuensi pendampingan dan } \\
\text { monitoring }\end{array}$ & $\begin{array}{l}\text { Hanya dilakukan oleh } \\
\text { dosen atau mahasiswa } \\
\text { secara terpisah }\end{array}$ & $\begin{array}{l}\text { Dilakukan oleh dosen } \\
\text { dan mahasiswa secara } \\
\text { terkoordinasi }\end{array}$ \\
\hline
\end{tabular}

Hasil dari kegiatan ini sesuai dengan pernyataan Rahmaveda (2017), bahwa sinergi merupakan hasil interaksi dan kondisi saling melengkapi dari bagian-bagian yang berbeda untuk mencapai hasil dan dampak gabungan yang lebih besar daripada apabila dilakukan sendiri oleh masing-masing bagian serta menghasilkan hal-hal yang baru yang dahulunya tidak ada. Deardorff dan Williams (2006) menegaskan bahwa sinergi merupakan bentuk melipat-gandakan pengaruh (multiplier effect) yang memungkinkan energi pekerjaan berlipat ganda secara eksponensial melalui usaha bersama. Oleh karena itu, berdasarkan hasil dari kegiatan ini, bentuk sinergi antara dosen dan mahasiswa yang telah dilakukan dalam kegiatan pengabdian masyarakat ini dapat direkomendasikan untuk diadopsi dalam kegiatan-kegiatan pengabdian masyarakat yang akan dilakukan selanjutnya. 


\section{KESIMPULAN}

Kegiatan ini dapat disimpulkan bahwa introduksi teknologi pengolahan ubi jalar ungu dan jagung menjadi tepung, cookies dan brownies kepada kelompok wanita tani di Desa Koripan, Kecamatan Matesih, Kabupaten Karanganyar dapat berjalan dengan baik. Sinergi antara dosen dan mahasiswa dalam melaksanakan kegiatan pengabdian masyarakat tersebut berjalan dengan efektif, sehingga kedua belah pihak mendapatkan manfaat dari sinergi tersebut. Model sinergi ini dapat diadopsi pada kegiatan-kegiatan pengabdian masyarakat yang akan dilakukan selanjutnya.

\section{UCAPAN TERIMA KASIH}

Penulis menyampaikan terima kasih kepada HIMAGHITA yang telah bersedia berkolaborasi dalam kegiatan pengabdian masyarakat ini. Kegiatan pengabdian masyarakat di Desa Koripan dapat terselenggara atas bantuan biaya dari Kementerian Pendidikan dan Kebudayaan Republik Indonesia melalui Hibah Kegiatan Pengabdian Pada Masyarakat Mono Tahun dalam skema IbM (Surat Perjanjian Pelaksanaan Penugasan Program Pengabdian kepada Masyarakat Nomor: 025/SP2H/KPM/DIT. LITABMAS/V/2013) untuk pelaksanaan kegiatan tahun 2013, serta bantuan dari Universitas Sebelas Maret melalui Hibah Kegiatan Pengabdian Pada Masyarakat Mono Tahun, dalam skema IbM Tahun 2014 yang dibiayai dari Dana DIPA BLU Universitas Sebelas Maret (Surat Perjanjian Pelaksanaan Kegiatan Pengabdian Masyarakat Nomor: 499/UN27.11/PN/2014) untuk kegiatan yang dilaksanakan pada Tahun 2014 .

\section{DAFTAR PUSTAKA}

Aini, N., Wijonarko, G., \& Sustriawan, B. (2016). Sifat fisik, kimia, dan fungsional tepung jagung yang diproses melalui fermentasi. Agritech, 36(2), 160-169. https://doi.org/ 10.22146/agritech. 12860

Deardorff, D. S., \& Williams, G. (2006). Synergy Leadership in Quantum Organizations. USA: Fesserdorff Consultants. Tersedia dari http://www.rockypeaklc.com/synleader08.pdf

Firgianti, G., \& Sunyoto, M. (2018). Karakterisasi fisik dan kimia ubi jalar ungu (Ipomoea batatas L.) varietas biang untuk mendukung penyediaan bahan baku tepung ubi jalar ungu. Prosiding Seminar Nasional Fakultas Pertanian UNS, 2(1), F-104. Tersedia dari https://jurnal.fp.uns.ac.id/index.php/semnas/ar ticle/view/1154

Hariyanto, D., Kurniawan, A. D., \& Yasmin, D. (2017). Pengintegrasian pendidikan, kesehatan, dan pendapatan dalam upaya meningkatkan derajat kesejahteraan masyarakat di Desa 3T. Buletin Al-Ribaath, 14(2), 61-67. http://dx.doi.org/10.29406/br. v14i2.879

HIMAGHITA. (2019). HIMAGHITA. Diakses pada 17 April 2019 dari http://fp.uns. ac.id/himaghita/

Mufidah, A. D., \& Adi, I. R. (2018). Pemberdayaan masyarakat oleh PT Nestle Indonesia melalui kelompok sapi perah Budi Luhur. Jurnal Ilmu Kesejahteraan Sosial, 19(2), 109-131. http://dx.doi.org/10.7454/ jurnalkessos.v19i2.169

Peraturan Pemerintah Republik Indonesia. (2009). Peraturan Pemerintah Republik Indonesia Nomor 37 Tahun 2009 Tentang Dosen. Tersedia dari http://sipma.ui.ac.id/ files/dokumen/U_DOSEN/PP\%2037\%20Tah un\%202009\%20DOSEN.pdf

Sari, S. B., Mukhtar, N., kasih, I. C., \& Anisa. (2018). Analisis faktor-faktor yang mempengaruhi keseringan mahasiswa Unhas mengikuti program GUMSB (Gerakan Unhas Mengaji dan Sholat Berjamaah) dengan model regresi logistik. Jurnal Matematika, Statistika dan Komputasi, 15(1), 104-113. https://doi. org/10.20956/jmsk.v15i1.4454

Rahmaveda, A. (2017). Pemberdayaan anak jalanan di Kota Surabaya (Sinergitas antar stakeholders dalam peningkatan kemandirian anak jalanan). Kebijakan dan Manajemen Publik, 5(3), 1-8. Tersedia dari http://journal. unair.ac.id/download-fullpapers-kmpb1f8369 8f2full.pdf

Riptanti, E. W., Qonita, A., \& Fajarningsih, R. U. (2018). Potentials of sustainable development of medicinal plants in Wonogiri regency of Central Java province of Indonesia. Bulgarian Journal of Agricultural Science, 24(5), 742749. Tersedia dari https://www.agrojournal. org/24/05-03.pdf 